\title{
Palm (Arecaceae) Communities in the Brazilian Atlantic Forest: a Phytosociological Study
}

\author{
Guilherme Alves Elias ${ }^{1}$ (D), Renato Colares ${ }^{1}$, Altamir Rocha Antunes ${ }^{1}$, \\ Peterson Teodoro Padilha ${ }^{1}$, Joanna Marie Tucker Lima ${ }^{2}$, Robson Santos ${ }^{1}$ \\ ${ }^{1}$ Universidade do Extremo Sul Catarinense - UNESC, Criciúma/SC, Brasil \\ ${ }^{2}$ Montgomery Botanical Center, Coral Gables/FL, USA
}

\begin{abstract}
The aim of this study was to improve our understanding of the structure and composition of native palm communities in the Brazilian Atlantic Forest. This study was carried out at "Parque Estadual da Serra Furada" (PAESF), a protected area located in southern state of Santa Catarina. A palm community survey was carried out in Dense Ombrophilous Forest in five $20 \mathrm{~m} \times 100 \mathrm{~m}$ sampling units, totaling $1 \mathrm{ha}$. All palm individuals were measured, totaling 11,183 plants, belonging to four genera and five species: Bactris setosa Mart., Euterpe edulis Mart., Geonoma gamiova Barb.Rodr., Geonoma schottiana Mart. and Syagrus romanzoffiana (Cham.) Glassman. Euterpe edulis was the most common species, contributing the most to all phytosociological parameters; however, relatively few large individuals were found. Our study demonstrates the limitations of traditional forest surveys that ignore smaller diameter palm species and highlights the importance of the role of this group in the floristic diversity, ecosystem function, environmental services and carbon dynamics.
\end{abstract}

Keywords: biodiversity, conservation area, Euterpe edulis, forest inventory, Palmae, phytosociology, Santa Catarina. 


\section{INTRODUCTION}

Palms belong to one of the largest plant families (Arecaceae) and represent a vital element of forest ecosystems, in terms of both ecological and economic importance (Reitz, 1974; Soares et al., 2014; Elias, 2018; Elias et al., 2016, 2018, 2019). With abundance of nutritious fruits and seeds, palms provide an essential resource for tropical forest frugivores (Zona \& Henderson, 1989; Andreazzi et al., 2009; Galetti et al., 2013; Vinholes, 2018). In addition, palms are key components of the forest structure, and can be found in all forest strata (canopy understory), although many tropical species have been extensively collected by humans, for both timber and non-timber uses (Ubessi-Macarini et al., 2011; Elias \& Santos, 2016; Elias et al., 2019).

Research on palm community structure in Brazil is relatively rare compared to other plant groups (Fisch \& Gomes, 2015) and is mostly limited to studies focused on the Cerrado (Campos et al., 2017) and Amazon domains (Salm et al., 2015). Furthermore, while studies on forest structure and composition in the Atlantic Forest are common (Colonetti et al., 2009; Portella \& Santos, 2014; Bosa et al., 2015); their methodologies, especially the inclusion criteria, often overlook important components of the forest structure, excluding some palm species due to their particular growth habit.

A better understanding of the palm population structure and dynamics is critical, as reduced densities and species loss due to forest fragmentation are important basic structural changes to palm communities, altering food chains and compromising the availability of basic resources (Carvalho et al., 2010).

The present work describes the structural characteristics (absolute and relative frequency; absolute and relative density; absolute and relative dominance; and Importance Value Index) of palm communities in a fragment of Dense Ombrophilous Forest at the "Parque Estadual da Serra Furada" (PAESF), southern Santa Catarina.

\section{MATERIAL AND METHODS}

\subsection{Study area}

The "Parque Estadual da Serra Furada" (PAESF) is located between Orleans and Grão Pará, two municipalities in the southern part of the Brazilian state of Santa Catarina (Figure 1). Historically, the area now occupied

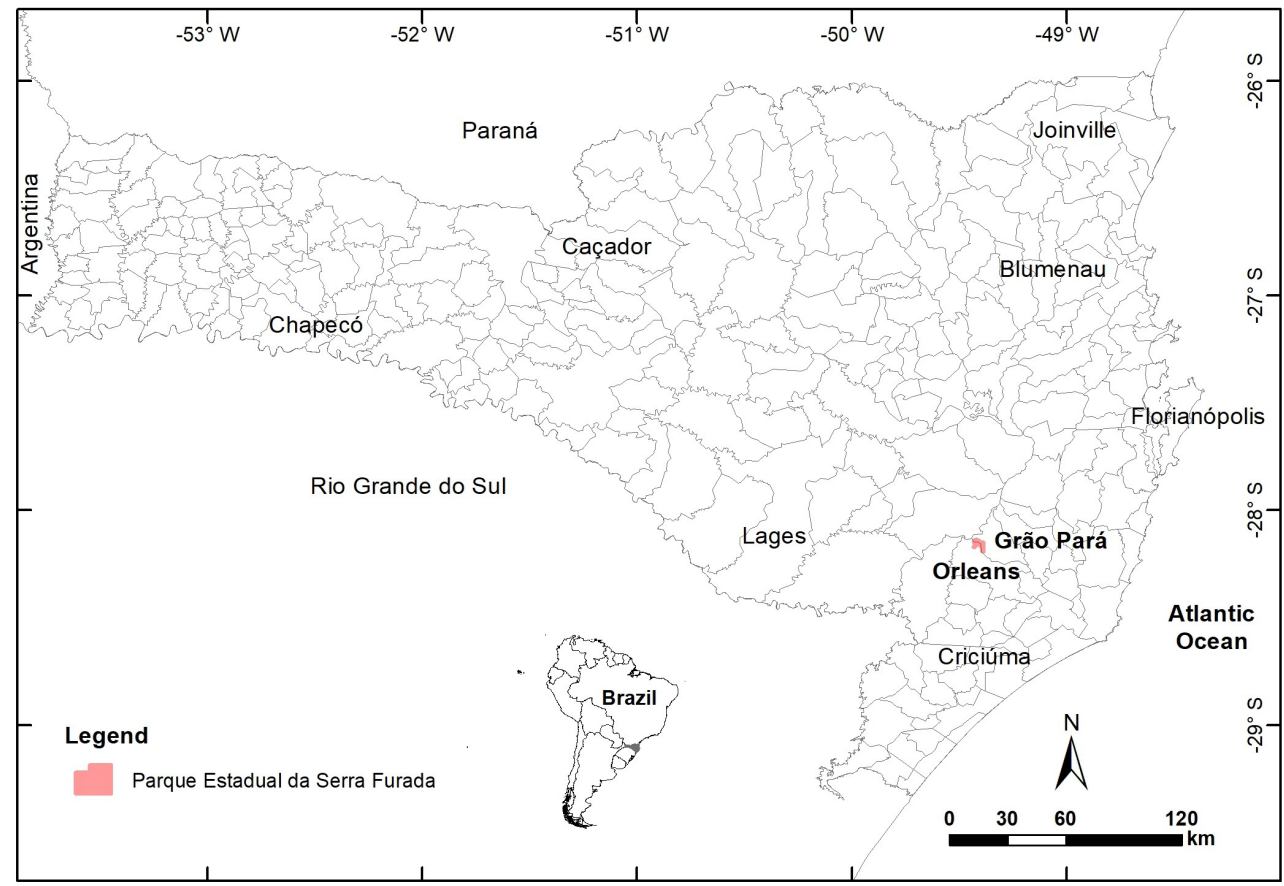

Figure 1. "Parque Estadual da Serra Furada" (PAESF) located between Orleans and Grão Pará, in the southern part of Santa Catarina, Brazil. 
by PAESF experienced unsupervised timber extraction and human disturbance until the creation of the park on June 20, 1980 (Decree No 11.233; Guislon et al., 2017). Hunting and collection of economically valuable species were widespread and led to the loss of much of the original biodiversity. Subsistence livestock farming and logging were widely practiced before the creation of the park and substantially altered the forest structure (Guislon et al., 2017). The vegetation of the study area presents high diversity of tree species, distributed across a mosaic of heterogeneous habitats, and includes species such as Alchornea triplinervia (Spreng.) M. Arg., Ocotea catharinensis Mez., Actinostemon concolor (Spreng.) Müll.Arg. and Guapira opposita (Vell.) Reitz (Guislon et al., 2017).

The Köppen climate classification for the PAESF region is humid subtropical with no defined dry season and hot summers (Cfa), with average annual temperature varying from $17.0^{\circ} \mathrm{C}$ to $19.3^{\circ} \mathrm{C}$ at lower altitudes, and balmy summers (Cfb) with average annual temperature ranging from $13.8^{\circ} \mathrm{C}$ to $15.8^{\circ} \mathrm{C}$ at higher altitudes (Alvares et al., 2013). Average annual rainfall ranges from $1,300 \mathrm{~mm}$ to $2,500 \mathrm{~mm}$
(Alvares et al., 2013). The PAESF terrain is rugged, characterized by craggy areas and steep valleys with altitudes from 400 to $1480 \mathrm{~m}$. The vegetation in the park is classified as Dense Ombrophilous Montane and High-Montane Forests (IBGE, 2012). In terms of geology, PAESF is characterized by extensive rock areas, such as siltstones, shales and sandstones included in the following lithostratigraphic classifications: São Bento Group, represented by diabase intrusion and by Serra Geral and Botucatu formations; Passa Dois Group, composed of Rio do Rastro, Terezina, Serra Alta and Irati formations; and Guatá Group, with non-glacial sediments and coal layers, composed of the Palermo Formation (IBGE, 2012).

\subsection{Data collection}

A palm community survey was carried out in Dense Ombrophilous Forest within five $20 \mathrm{~m} \times 100 \mathrm{~m}$ sampling units (SU), or plots, totaling 1ha (Figure 2). The first sampling unit (A) was installed five meters from the forest edge in an area with history of intense exploitation by past residents and located close to PAESF headquarters. The second sampling unit (B) was installed
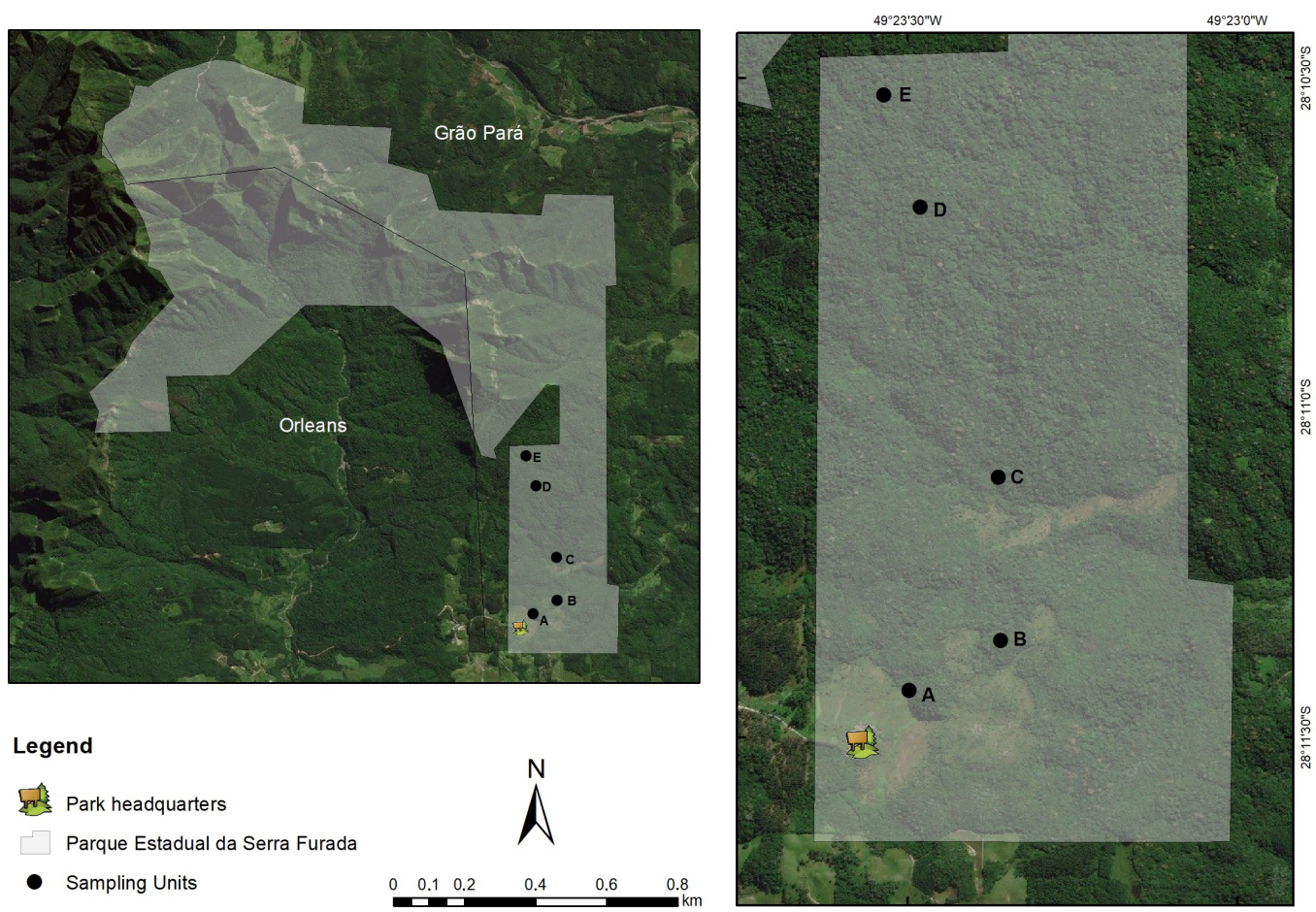

Figure 2. Sampling Unit (SU) locations within the "Parque Estadual da Serra Furada" (PAESF) boundary, located between municipalities of Orleans and Grão Pará, Santa Catarina, Brazil. 
within the forest interior on sloping ground with little history of human intervention. The third sampling unit (C) was installed nearby streams and waterfalls and surrounded by rugged terrain. The fourth and fifth sampling units (D and E) were located in selectively logged forest at higher altitudes and far from any water bodies. Sampling units ranged in altitude from 470 to $650 \mathrm{~m}$ (Guislon et al., 2017). All palms from seedlings to adults were measured and identified in each plot. Height at the top of leaf crown was measured using a laser measure tape (Bosch GLM 40), and Diameter at Soil Height (DSH) of each palm was measured using a digital caliper (MTX - 150mm).

\subsection{Data analysis}

To analyze the horizontal and vertical structure of PAESF palm populations, the DSH distribution (Diameter at Soil Height) and height classes separated into 15 size classes based on Sturges (1926) were examined.

Data were standardized, and non-metric multidimensional ordination methods (NMDS) (Clarke, 1993) and the Bray-Curtis index were used to determine associations and distinct groups among SUs using species abundance as variable. Analysis of similarity (ANOSIM) (Clarke, 1993) was then applied with 999 permutations to determine significance of assigned groups. All palm species were included in these analyses.

To characterize the horizontal structure of each group, as determined by NMDS and ANOSIM, Importance Value (IV) was calculated, which is the sum of the relative frequency, density and dominance values for each species. Finally, the species that most contributed to differences between groups were identified using analysis of similarity (SIMPER) (Clarke, 1993). Statistical analyses were run in the $\mathrm{R}$ computing environment (R Development Core Team, 2018).

\section{RESULTS AND DISCUSSION}

Overall, 11,183 individual palms belonging to four genera and five species were surveyed: Bactris setosa Mart., Euterpe edulis Mart., Geonoma gamiova Barb.Rodr., Geonoma schottiana Mart. and Syagrus romanzoffiana (Cham.) Glassman. This high palm abundance was directly related to our methodology, which included all individuals, regardless of size.
Recently, Fisch \& Gomes (2015) reviewed sampling methods and floristic and structural parameter calculations across six palm community studies in different vegetation types. Among studies, only one calculated dominance, which was based on palms with $\mathrm{DBH} \geq 2 \mathrm{~cm}$, thus excluding small stature and stemless palms and underestimating the true extent of the palm community (Elias et al., 2018). Generally, forest inventories exclude trees with $\mathrm{DBH} \leq 2 \mathrm{~cm}$, but their diverse growth habits, including reproductively mature stemless and small stature specimens, dictate a more inclusive methodology for studying the composition and structure of palm communities and forests containing palms.

This study included all palms regardless of size and evaluated population stratification across 15 size classes defined based on the formula of Sturges. C1, C2 and C3 classes corresponded to more than 90\% of sampled individuals, demonstrating the dominance of young and short-stature individuals and depicting an "inverted j" pattern (Table 1), typical of natural populations that present high in locus regeneration (Rocha, 2004). The same pattern was reported for E. edulis (Reis et al., 1996) and several other neotropical palms growing in Santa Catarina (Elias et al., 2019).

C10 class also included many individuals and is mainly composed of E. edulis palms, which grow 10-12 $\mathrm{m}$ in height. Field observations confirmed that these individuals are reproductive, showing signs of flowering and fruiting. Reitz (1974) also observed fertile individuals within this size class in Santa Catarina. In contrast, E. edulis individuals from the initial classes showed high mortality rate, following the "inverted j" pattern, with only $5.5 \%$ and $1.2 \%$ in C1 class, reaching the second and third size classes, respectively. This high mortality rate is linked to genetic potential, the microenvironment and intra and interspecific competition (Reis et al.,1996).

Bactris setosa, G. gamiova and G. schottiana exhibited lower abundance compared to E. edulis and were distributed among fewer height classes. As understory species, these palms rarely grow over 3.5 meters in height (Elias et al., 2018). These species show signs of flowering and fruiting at heights above $1.24 \mathrm{~m}$ in the second size class.

All Syagrus romanzoffiana palms were included in the smallest size class (C1). This palm is a large 
arborescent palm, rarely found in PAESF, but known for its high environmental plasticity (Elias et al., 2016). The concentration of smaller individuals found here suggests that $S$. romanzoffiana is beginning to colonize forest communities in the park, probably due to the presence of new seed dispersers (Giombini et al., 2009).

The distribution of DSH classes presented pattern similar to height class distributions (Table 2). The three smallest classes $(<52.8 \mathrm{~mm})$ corresponded to more than $98 \%$ of sampled individuals and represented more than $35 \%$ of the basal area within the community, but smaller individuals also demonstrated high mortality rate (Swaine et al., 1987).

Our findings highlight loss of information with the exclusion of smaller diameter individuals - a common practice in plant population studies. For palms in particular, this restrictive methodology excludes meaningful information regarding reproductive and ecologically important understory plants that fail to meet minimum size requirements. By including all palms, this study ensured that smaller diameter and stemless palms were sampled to better understand the

Table 1. Palm distribution by height classes $(\mathrm{m})$ for all palms sampled in five $20 \mathrm{~m} \times 100 \mathrm{~m}$ sampling units within PAESF, Santa Catarina, Brazil.

\begin{tabular}{clccccccc}
\hline Class & Height $(\mathbf{m})$ & Bac.set & Eut.edu & Geo.gam & Geo.sch & Sya.rom & RA \\
\hline C1 & $(0.04-1.24)$ & 58 & 9244 & 1019 & 51 & 8 & 92.82 \\
C2 & $(1.24-2.43)$ & 11 & 245 & 115 & 11 & 0 & 3.42 \\
C3 & $(2.43-3.63)$ & 3 & 60 & 73 & 8 & 0 & 1.29 \\
C4 & $(3.63-4.83)$ & 2 & 12 & 12 & 0 & 0 & 0.23 \\
C5 & $(4.83-6.03)$ & 0 & 10 & 0 & 0 & 0 & 0.09 \\
C6 & $(6.03-7.22)$ & 0 & 72 & 0 & 0 & 0 & 0.64 \\
C7 & $(7.22-8.42)$ & 0 & 11 & 0 & 0 & 0 & 0.10 \\
C8 & $(8.42-9.62)$ & 0 & 12 & 0 & 0 & 0 & 0.11 \\
C9 & $(9.62-10.82)$ & 0 & 8 & 0 & 0 & 0 & 0.07 \\
C10 & $(10.82-12.01)$ & 0 & 126 & 0 & 0 & 0 & 1.13 \\
C11 & $(12.01-13.21)$ & 0 & 8 & 0 & 0 & 0 & 0.07 \\
C12 & $(13.21-14.41)$ & 0 & 1 & 0 & 0 & 0 & 0.01 \\
C13 & $(14.41-15.61)$ & 0 & 1 & 0 & 0 & 0 & 0.01 \\
C14 & $(15.61-16.80)$ & 0 & 1 & 0 & 0 & 0 & 0.01 \\
\hline C15 & $(16.80-18.00)$ & 0 & 1 & 0 & 0 & 0 & 0.01 \\
\hline
\end{tabular}

Table 2. Palm distribution by DSH classes $(\mathrm{mm})$ for all palms sampled in five $20 \mathrm{~m} \times 100 \mathrm{~m}$ sampling units within PAESF, Santa Catarina, Brazil.

\begin{tabular}{|llcccccccc} 
Classes & DSH $(\mathbf{m m})$ & Bac.set & Eut.edu & Geo.gam & Geo.sch & Sya.rom & RA & RBA \\
C1 & $(1.0-18.3)$ & 54 & 9137 & 629 & 25 & 8 & 88.11 & 9.28 \\
C2 & $(18.3-35.5)$ & 14 & 425 & 464 & 27 & 0 & 8.32 & 16.31 \\
C3 & $(35.5-52.8)$ & 4 & 99 & 99 & 8 & 0 & 1.88 & 9.50 \\
C4 & $(52.8-70.1)$ & 2 & 56 & 21 & 9 & 0 & 0.79 & 8.57 \\
\hline C5 & $(70.1-87.3)$ & 0 & 15 & 3 & 1 & 0 & 0.17 & 2.97 \\
C6 & $(87.3-104.6)$ & 0 & 7 & 0 & 0 & 0 & 0.06 & 1.64 \\
C7 & $(104.6-121.9)$ & 0 & 7 & 1 & 0 & 0 & 0.07 & 2.59 \\
C8 & $(121.9-139.1)$ & 0 & 14 & 0 & 0 & 0 & 0.13 & 6.08 \\
C9 & $(139.1-156.4)$ & 0 & 17 & 0 & 0 & 0 & 0.15 & 9.21 \\
C10 & $(156.4-173.7)$ & 0 & 13 & 1 & 0 & 0 & 0.13 & 9.39 \\
C11 & $(173.7-190.9)$ & 0 & 10 & 1 & 0 & 0 & 0.10 & 9.49 \\
C12 & $(190.9-208.2)$ & 0 & 4 & 0 & 0 & 0 & 0.04 & 3.98 \\
C13 & $(208.2-225.5)$ & 0 & 4 & 0 & 0 & 0 & 0.04 & 4.72 \\
C14 & $(225.5-242.7)$ & 0 & 1 & 0 & 0 & 0 & 0.01 & 1.34 \\
C15 & $(242.7-260.0)$ & 0 & 3 & 0 & 0 & 0 & 0.03 & 4.92 \\
\hline
\end{tabular}

Bac.set $=$ Bactris setosa Eut.edu $=$ Euterpe edulis; Geo.gam $=$ Geonoma gamiova $;$ Geo. sch $=$ Geonoma schottiana Sya.rom $=$ Syagrus romanzoffiana $\mathrm{RA}=$ relative class abundance; and $\mathrm{RBA}=$ relative basal area. 
role of these palms in the structure and dynamics of the Atlantic Forest community (Fisch \& Gomes, 2015).

\subsection{Distribution on sampling units}

Palms occurred throughout all SUs; however, ordination analysis identified two distinct palm communities, separating $\mathrm{SU}(\mathrm{A})$ from all others $(\mathrm{B}, \mathrm{C}, \mathrm{D}$, and $\mathrm{E})$ (Figure 3). Differences were related to past land use history. Before PAESF was officially demarcated, SU (A) experienced heavy exploitation - mainly the harvest of E. edulis palm heart. Even after demarcation, forest reserves were still plagued by illegal harvesting, a common practice in Santa Catarina (Gasper et al., 2011). For example, Silva \& Fisch (2012) reported illegal palm heart extraction in protected areas of the "Parque Estadual da Serra do Mar" in Ubatuba, along the northern coast of the state of São Paulo.

SUs (B, C, D and E) were grouped together despite different intervention histories and distinct environmental contexts. One of the main reasons for this procedure was the considerable distance of each SU from the park boundary and difficult access to these areas. ANOSIM also confirmed the separation of SUs into the same two distinct groups $(\mathrm{R}=0.80 ; P=0.001)$ : environments with high intensity exploitation (A) were significantly different from those with low impact exploitation (B, C, D and E).

Relative frequency, density, dominance, and importance values showed no clear differences among the four SUs (B, C, D and E), while absolute palm

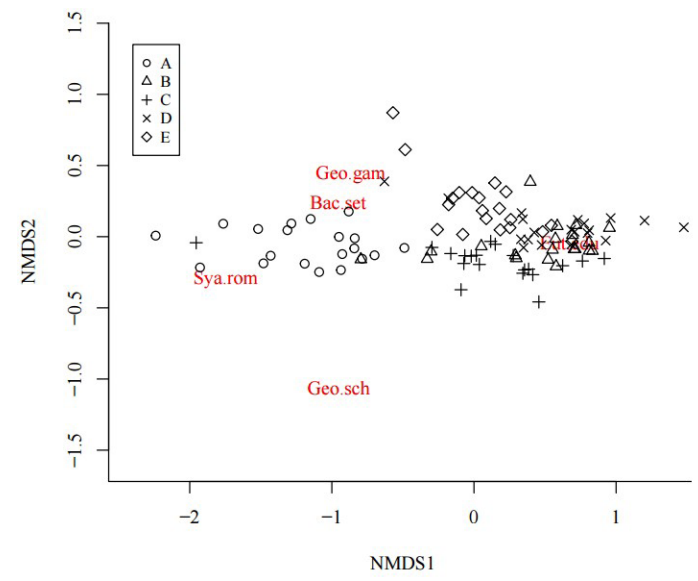

Figure 3. Multidimensional non-metric scaling for sampled palm species, according to the different Sampling Units (A, B, C, D, and E). Stress: 0.044 (2 dimensions). density in SU (A) was, on average, five times lower than in the other SUs. This contrast reflects land use history, especially the extraction of E. edulis stems for palm heart and the exploitation of other economically valuable species, which altered luminosity and the presence of propagules in the area, reducing the abundance of species typical to these environments, as observed in other forest fragments of Santa Catarina (Gasper et al., 2011).

SIMPER analysis pointed E. edulis as key for distinction among environments, corresponding to $84 \%$ of dissimilarity, followed by G. gamiova (14\%). In addition, E. edulis presented the highest IVI across all SUs (Table 3). This species dominates all layers of the forest strata and at times, it appears monodominant. Reitz (1974) also emphasized the importance of E. edulis in the Dense Ombrophilous Forests of Santa Catarina, and our results corroborate Oliveira et al. (2014), who identified E. edulis as the most abundant palm species of Ubatuba, state of São Paulo.

Geonoma gamiova was also important to the palm community surveyed here. In total, 1219 individuals of this thin-stemmed species were recorded in nearly all SUs. Geonoma gamiova was spared during PAESF's logging period, due to its use as a non-timber forest product, such as rope and roofing that crafted from leaves (Reitz, 1974). The species has few environmental restrictions (Oliveira et al., 2014) and is regularly distributed throughout the Dense Ombrophilous Forest understory (Henderson, 2011; Elias et al., 2018).

Bactris setosa and G. schottiana occurred at low densities with only 74 and 70 individuals, respectively. Both species are selective in terms of habitat conditions. The rugged terrain found within PAESF does not provide ideal establishment conditions for $B$. setosa, which prefers wet soils, nor for G. schottiana, which develops better at higher altitudes (Reitz, 1974; Elias et al., 2018).

Syagrus romanzoffiana was the least abundant palm species in PAESF, with only 12 individuals all shorter than $1.2 \mathrm{~m}$. This large arborescent palm can reach $15 \mathrm{~m}$ and shows natural regeneration inside the forest, especially in forest gaps. The dispersion of S. romanzoffiana seeds into PAESF originates from only a few seed sources, although mammal feces containing many seeds are frequently found. We believe that with time, $S$. romanzoffiana will become increasingly common in PAESF, as well as throughout the state of Santa Catarina (Elias et al., 2016). 
Table 3. Palm community composition parameters, ordered by Importance Value Index, for species sampled at "Parque Estadual da Serra Furada" (PAESF), Santa Catarina, Brazil.

\begin{tabular}{|c|c|c|c|c|c|c|c|}
\hline \multicolumn{8}{|c|}{ Environment with high levels of exploitation (Sampling Unit A) } \\
\hline Species & AF & RF & AD & RD & ADO & RDO & IVI \\
\hline Euterpe edulis & 100 & 48.78 & 1800 & 89.11 & 0.08 & 65.56 & 203.45 \\
\hline Geonoma gamiova & 75 & 36.59 & 190 & 9.41 & 0.03 & 25.94 & 71.93 \\
\hline Bactris setosa & 15 & 7.32 & 15 & 0.74 & 0.00 & 3.06 & 11.12 \\
\hline Geonoma schottiana & 10 & 4.88 & 10 & 0.50 & 0.01 & 5.39 & 10.76 \\
\hline Syagrus romanzoffiana & 5 & 2.44 & 5 & 0.25 & 0.00 & 0.05 & 2.74 \\
\hline Total & 205.00 & 100 & 2020 & 100 & 0.12 & 100 & 300 \\
\hline \multicolumn{8}{|c|}{ Environment with low levels of exploitation (Sampling Units B, C, D and E) } \\
\hline Species & AF & RF & AD & RD & ADO & RDO & IVI \\
\hline Euterpe edulis & 100 & 39.41 & 11815 & 87.69 & 3.04 & 79.04 & 206.13 \\
\hline Geonoma gamiova & 95 & 37.44 & 1476.25 & 10.96 & 0.71 & 18.39 & 66.78 \\
\hline Bactris setosa & 40 & 15.76 & 88.75 & 0.66 & 0.03 & 0.68 & 17.10 \\
\hline Geonoma schottiana & 12.5 & 4.93 & 85.00 & 0.63 & 0.07 & 1.87 & 7.43 \\
\hline Syagrus romanzoffiana & 6.25 & 2.46 & 8.75 & 0.06 & 0.00 & 0.03 & 2.56 \\
\hline Total & 253.75 & 100 & 13473.75 & 100 & 3.84 & 100 & 300 \\
\hline
\end{tabular}

$\mathrm{AF}=$ Absolute Frequency; $\mathrm{RF}=$ Relative Frequency; $\mathrm{AD}=$ Absolute Density; $\mathrm{RD}=$ Relative Density; $\mathrm{ADO}=\mathrm{Absolute}$ Dominance; $\mathrm{RDO}=$ Relative Dominance; IVI = Importance Value Index

\section{CONCLUSIONS}

Euterpe edulis dominated PAESF palm communities; however, relatively few large palms were found. Considering high mortality rates in smaller size classes, this scarcity of reproductive individuals compromises the continuity of the population and the ecosystem services they provide. On the other hand, Bactris setosa, G. gamiova and G. schottiana exhibited lower abundance compared to E. edulis, mainly due to their narrow habitat requirements, but significantly contributed to the diversity and biomass of the overall palm community.

Past land use history and the collection of E. edulis stems for palm heart left a lasting negative result on palm communities found within PAESF. Future management plans and conservation initiatives in this area should take into account the importance of this palm and its fragility in the forest.

The abundance of palms recorded in our survey at PAESF demonstrates the limitations of traditional forest surveys that ignore smaller diameter species $(\mathrm{DBH} \leq 2 \mathrm{~cm})$. The exclusion of shorter height understory palms leads to a misrepresentation of the true forest community, and we suggest that forest ecology studies use less restrictive criteria for palms in order to avoid underestimating the role of this group in the floristic diversity, ecosystem function, environmental services and carbon dynamics.

\section{ACKNOWLEDGEMENTS}

We acknowledge financial support from the Coordination for the Improvement of Higher Education Personnel (CAPES) for the first author's scholarship funding, the University of Extremo Sul Catarinense (UNESC) for infrastructure and Institute of Environment of Santa Catarina (IMA) for license for the study development.

\section{SUBMISSION STATUS}

Received: 15 june, 2018

Accepted: 20 july, 2019

\section{CORRESPONDENCE TO}

\section{Guilherme Alves Elias}

Programa de Pós-graduação em Ciências Ambientais, Universidade do Extremo Sul Catarinense - UNESC, Av. Universitária, Bairro Universitário, Herbário CRI, CEP 88806-000, Criciúma, SC, Brasil e-mail: guilherme@unesc.net 


\section{REFERENCES}

Alvares CA, Stape JL, Sentelhas PC, Gonçalves JLM, Sparovek G. Köppen's climate classification map for Brazil. Meteorologische Zeitschrift 2013; 22(6): 711-728. http:// dx.doi.org/10.1127/0941-2948/2013/0507.

Andreazzi CS, Pires AS, Fernandez FAS. Mamíferos e palmeiras neotropicais: interações em paisagens fragmentadas. Oecologia Brasiliensis 2009; 13(4): 554-574.

Bosa DM, Pacheco D, Pasetto MR, Santos R. Florística e estrutura do componente arbóreo de uma floresta ombrófila densa montana em Santa Catarina, Brasil. Revista Árvore 2015; 39(1): 49-58. http://dx.doi.org/10.1590/010067622015000100005 .

Campos JLA, Albuquerque UP, Peroni N, Araújo EL. Population structure and fruit availability of the babassu palm (Attaleaspeciosa Mart. ex Spreng) in humandominated landscapes of the Northeast Region of Brazil. Acta Botanica Brasílica 2017; 31(2): 267-275. http://dx.doi. org/10.1590/0102-33062016abb0255.

Carvalho AL, Ferreira EJL, Lima JMT. Comparações florísticas e estruturais entre comunidades de palmeiras em fragmentos de floresta primária e secundária da Área de Proteção Ambiental Raimundo Irineu Serra, Rio Branco, Acre, Brasil. Acta Amazonica 2010; 40(4): 657-666. http:// dx.doi.org/10.1590/S0044-59672010000400004.

Clarke KR. Non-parametric multivariate analyses of changes in community structure. Austral Ecology 1993; 18(1): 117-143. http://dx.doi.org/10.1111/j.1442-9993.1993. tb00438.x.

Colonetti S, Citadini-Zanette V, Martins R, Santos R, Rocha E, Jarenkow JA. Florística e estrutura fitossociológica em Floresta Ombrófila Densa Submontana na barragem do rio São Bento, Siderópolis, Estado de Santa Catarina. Acta Scientiarum. Biological Sciences 2009; 31(4): $397-$ 405. http://dx.doi.org/10.4025/actascibiolsci.v31i4.3345.

Elias GA. Palmeiras (Arecaceae) em Santa Catarina, Sul do Brasil. Revista Brasileira de Agroecologia 2018; 13(5): 262-263.

Elias GA, Gasper AL, Lima JMT, Soares KP, Molz M, Santos R. Community structure of large native arborescent palms (Arecaceae) using data from the Floristic and Forest Inventory of Santa Catarina, Brazil. Australian Journal of Basic and Applied Sciences 2016; 10(10): 156-163.

Elias GA, Gasper AL, Lima JMT, Lodetti G, Santos R. Native understory palms (Arecaceae) of the Atlantic Forest in Santa Catarina, Southern Brazil. Rodriguésia 2018; 69(2): 693-698. http://dx.doi.org/10.1590/2175-7860201869230.

Elias GA, Santos R. Produtos florestais não madeireiros e valor potencial de exploração sustentável da Floresta Atlântica no sul de Santa Catarina. Ciência Florestal 2016; 26(1): 249-262. http://dx.doi.org/10.5902/1980509821117.
Elias GA, Soares KP, Bortoluzzi RLC, Santos R. Palmeiras (Arecaceae) em Santa Catarina, sul do Brasil. Iheringia. Série Botânica 2019; 73(2): 88-107. http://dx.doi. org/10.21826/2446-8231201873202.

Fisch ATV, Gomes EPC. Métodos de amostragem de palmeiras (Arecaceae) e estudo de caso na restinga de Ubatuba, Estado de São Paulo, Brasil. In: Eisenlohr PV, Felfili JM, Melo MMRF, Meira JAA No, editors. Fitossociologia no Brasil: métodos e estudos de casos. Vol. 2. Viçosa: UFV; 2015.

Galetti M, Guevara R, Cortes MC, Fadini R, Von Matter S, Leite $\mathrm{AB}$ et al. Functional extinction of birds drives rapid evolutionary changes in seed size. Science 2013; 340(6136): 1086-1090. http://dx.doi.org/10.1126/science.1233774. PMid:23723235.

Gasper AL, Sevegnani L, Vibrans AC, Uhlmann A, Lingner DV, Verdi $\mathrm{M}$ et al. Inventário de Dicksonia sellowiana Hook. em Santa Catarina. Acta Botanica Brasílica 2011; 25(4): 776-784. http://dx.doi.org/10.1590/ S0102-33062011000400005.

Giombini MI, Bravo SP, Martinez MF. Seed dispersal of the palm Syagrus romanzoffiana by tapirs in the semi-deciduous Atlantic Forest of Argentina. Biotropica 2009; 41(4): 408-413. http://dx.doi.org/10.1111/j.17447429.2009.00526.x.

Guislon AV, Elias GA, Bernardo VM, Assunção VK, Santos R. Histórico de uso e ocupação da Floresta Atlântica em uma Unidade de Conservação no Sul do Brasil. Fronteiras 2017; 6(2): 47-64. http://dx.doi.org/10.21664/22388869.2017v6i2.p47-64.

Henderson A. A revision of Geonoma (Arecaceae). Phytotaxa 2011; 17(1): 1-271. http://dx.doi.org/10.11646/ phytotaxa.17.1.1

Instituto Brasileiro de Geografia e Estatística - IBGE. Manual técnico da vegetação brasileira. 2. ed. Rio de Janeiro: IBGE; 2012.

Oliveira KF, Fisch STV, Duarte JS, Danelli MF, Martins LFS, Joly CA. Estrutura e distribuição espacial de populações de palmeiras em diferentes altitudes na Serra do Mar, Ubatuba, São Paulo, Brasil. Rodriguésia 2014; 65(4): $1043-$ 1055. http://dx.doi.org/10.1590/2175-7860201465414.

Portella RCQ, Santos FAM. Impact of forest fragment size on the population structure of three palm species (Arecaceae) in the Brazilian Atlantic Rainforest. Revista de Biología Tropical 2014; 62(2): 433-442. PMid:25102629.

$\mathrm{R}$ Development Core Team. $R$ : a language and environment for statistical computing [online]. Vienna: R Foundation for Statistical Computing; 2018 [cited 2018 July 7]. Available from: http://www.R-project.org

Reis A, Kageyama PY, Reis MS, Fantini AC. Demografia de Euterpe edulis Martius (Arecaceae) em uma Floresta Ombrófila Densa Montana em Blumenau, SC. Sellowia 1996; 45-48: 13-45. 
Reitz R. Palmeiras. In: Reitz R, editor. Flora ilustrada catarinense. Itajaí: Herbário Barbosa Rodrigues; 1974.

Rocha E. Potencial ecológico para o manejo de frutos de açaizeiro (Euterpe precatoria Mart.) em áreas extrativistas no Acre, Brasil. Acta Amazonica 2004; 34(2): 237-250. http://dx.doi.org/10.1590/S0044-59672004000200012.

Salm R, Prates A, Simões NR, Feder L. Palm community transitions along a topographic gradient from floodplain to terra firme in the eastern Amazon. Acta Amazonica 2015; 45(1): 65-74. http://dx.doi.org/10.1590/18094392201401533

Silva LM, Fisch STV. Utilização de palmeiras nativas da Floresta Atlântica pela comunidade do entorno do Parque Estadual da Serra do Mar, Ubatuba, SP. Revista Biociências 2012; 18: 77-85.

Soares KP, Longhi SJ, Witeck L No, Assis LC. Palmeiras do Rio Grande do Sul, Brasil. Rodriguésia 2014; 65(1): 113 139. http://dx.doi.org/10.1590/S2175-78602014000100009.
Sturges HA. The choice of a Class Interval. Journal of the American Association 1926; 21(153): 65-66. http://dx.doi. org/10.1080/01621459.1926.10502161.

Swaine MD, Lieberman D, Putz FE. The dynamics of tree populations in tropical forest: a review. Journal of Tropical Ecology 1987; 3(4): 359-366. http://dx.doi.org/10.1017/ S0266467400002339.

Ubessi-Macarini C, Negrelle RRB, Souza MC. Produtos florestais não-madeiráveis e respectivo potencial de exploração sustentável, associados à remanescente florestal ripário do alto rio Paraná, Brasil. Acta Scientiarum. Biological Sciences 2011; 33(4): 451-462.

Vinholes AR. Interações entre aves frugívoras e Euterpe Edulis Mart. na Mata Atlântica no Sul de Santa Catarina: abordagem ecológica e etnoecológica. Revista Brasileira de Agroecologia 2018; 13(5): 260-261.

Zona S, Henderson A. A review of animal-mediated seed dispersal of palms. Selbyana 1989; 11: 6-21. 